\title{
ECONOMIC ANALYSIS OF THREE PREDOMINANT POULTRY PRODUCTION SYSTEMS IN THE RURAL SECTOR OF FAYOUM GOVERNORATE
}

\author{
Y.A.A. Abdel-Aziz ${ }^{1}$, H.B. Sammour ${ }^{2}$, O.M. Zatter ${ }^{1}$, M.A. El-Wardani ${ }^{1}$ \\ and Amal S. Omar ${ }^{1}$
}

1- Animal Production Research Institute, Agricultural Research Center, Ministry of Agriculture, Dokki, Giza, 2- Agricultural Economic Research Institute, Agriculture Research Center, Ministry of Agriculture, Dokki, Giza

\section{SUMMARY}

This study aimed at analyzing the present situation of the two most common poultry production systems in the rural sector of Fayoum, namely the traditional and the landless systems. Indicators of economic features were estimated and analyzed using data obtained from a sample of 120 poultry producers selected from 12 villages in six districts in the rural sector of the governorate. Two sources of data were used: 1-The primary data which were obtained from a questionnaire conducted in the study area and 2- available published reports by the Ministry of Agriculture and Land Reclamation, 2005.

Egg production and meat production were operated as separate activities. The measures of economic efficiency of laying chickens in the traditional poultry production system were better than the landless poultry production system as the gross margin of egg laying were about L.E.30.21and L.E.26.12 / bird/cycle (year) in the two systems, respectively, while the ratio of the total revenue/total variable costs were about L.E. 1.72, and L.E. 1.54 for the two systems, respectively. Meat production was mainly from local balady strains where birds were fattened in 150day cycles. Estimates of the gross margin of $\mathrm{kg}$ of meat were = L.E. 2.89, L.E. 2.87, and the total revenues/ total variable cost were L.E.1.39, LE.1.33 / bird /cycle for both systems, respectively.

Keywords: Landless, traditional, chickens, total costs, revenues, gross margin

\section{INTRODUCTION}

Poultry industry is one of the important agricultural industries in Egypt as about LE 17 billion are invested in it. The value of meat and egg production is estimated in current prices at LE 9.79 billion which represents about $21 \%$ of the total cash revenues of the animal production sector (Ministry of Agriculture and Land Reclamation (MALR, 2005). The actual broiler and egg production of both commercial and rural sectors was about 596.6 million birds, and 4.2 billion eggs from which about $17 \%$ of the broiler and $29 \%$ of the eggs were produced by the rural sector.

Issued by The Egyptian Society of Animal Production 
In spite of the importance of the rural sector of poultry production, little has been done to collect and study field data to overcome the shortage of information on this sector. Such research is needed to improve the efficiency of the production systems in the rural areas. The present research aims at studying the current situation of the rural poultry production in view of the economic features and economic efficiency of the systems.

\section{MATERIAL AND METHODS}

Data collected on 120 farmers living in 12 villages, two in each of the six districts of Fayoum (Table 1) were study. Pre-study information on the villages and farmers were obtained from the available statistics at the local Directorate of Animal Production. Thus the sample can be considered as a multistage random sample.

Table 1. Distribution of the sampled farmers

\begin{tabular}{|c|c|c|}
\hline District & Village & No. of farmers \\
\hline \multirow[t]{2}{*}{ Fayoum } & Kerdasa-corner & 9 \\
\hline & El-azab & 10 \\
\hline \multirow[t]{2}{*}{ Senores } & El-kaby & 10 \\
\hline & Senhor-elkiblia & 10 \\
\hline \multirow[t]{2}{*}{ Tamia } & Kafr-mahfoz & 11 \\
\hline & Bandr-tamia & 10 \\
\hline \multirow[t]{2}{*}{ Ebshawi } & Abu-denkash & 11 \\
\hline & Abu-kesah & 10 \\
\hline \multirow[t]{2}{*}{ Elsdiek } & Kasr-elgebali & 9 \\
\hline & Batn-haried & 10 \\
\hline \multirow[t]{2}{*}{ Atsah } & El-gafra & 10 \\
\hline & Gordo & 10 \\
\hline Total no. of farmers & & 120 \\
\hline
\end{tabular}

The data were collected during three months (March 25, to June 25, 2007) using a specially designed questionnaire to collect information on: size of the poultry flock, housing system, feeding system, marketing, vaccination and disease situation, production performance, fixed and variable costs, and revenues.

For better understanding of the overall situation of the farm, the questionnaire also included general information on the farmer and his family, his total cultivated area and the size of large and small ruminant herd if found. The study also considered a secondary source of information including data and reports published by the MALR, 2005 on the subject.

Economic variables were estimated, and measures of economic efficiency were used to evaluate the efficiency of the production systems followed in the study area.

Analysis of variance was performed to test the difference between systems, among districts, and between villages within districts. The following fixed effects model was proposed to underly each observation:

$\log \left(y_{i j k}\right)=u+S_{i}+D_{j}+V_{k}\left(D_{j}\right)+e_{i j k}$

$\log \left(y_{i j k}\right)=$ the yijk observation transformed to its log. The observation were taken on $\mathrm{CP}=$ chick price $; \mathrm{FC}=$ feed cost $; \mathrm{LC}=$ labour cost $; \mathrm{LIC}=$ litter cost $; \mathrm{WC}=$ water $\&$ electricity cost; 
$\mathrm{VC}=$ veterinary $\&$ drug cost $; \mathrm{TC}=$ total cost $; \mathrm{ER}=$ egg revenues $; \mathrm{CMR}=$ chicken $\&$ manure revenues ; $\mathrm{TR}=$ total revenues $; \mathrm{GM}=\mathrm{Gross}$ margin $; \mathrm{TR} / \mathrm{TC}=$ total revenues $/$ total variable costs for layer production and $: \mathrm{CP}=$ chick price $; \mathrm{FC}=$ feed cost $; \mathrm{LC}=$ labour cost $; \mathrm{LIC}=$ litter cost $; \mathrm{WC}=$ water $\&$ electricity cost $; \mathrm{VC}=$ veterinary $\&$ drug cost $; \mathrm{TC}=$ total cost $; \mathrm{TR}=$ total revenues $; \mathrm{GM}=\mathrm{Gross}$ margin $; \mathrm{TR} / \mathrm{TC}=$ total revenues $/$ total variable costs $\mathrm{AC} / \mathrm{KG}=$ average cost $/ 1 \mathrm{~kg}$ meat $; \mathrm{GM} / \mathrm{KG}=$ gross margin/1 kg meat تحليلي for meat productionl

$\mathrm{u}=$ common mean

$\mathrm{S}_{\mathrm{i}}=$ the effect of the $\mathrm{i}$ system, $\mathrm{i}=1,2$

$\mathrm{D}_{\mathrm{j}}=$ the effect of the $\mathrm{j}$ district, $\mathrm{j}=1,2, \ldots \ldots 6$

$\mathrm{V}_{\mathrm{k}}=$ the effect of $\mathrm{k}$ village within the $\mathrm{j}$ district, $\mathrm{k}=1,2$

$\mathrm{e}_{\mathrm{ijk}}=$ an error attached to the $\mathrm{ijk}$ observation, assumed to be independent, random, and normally distributed.

SPSS (2006) computer program for windows was used in the calculations, and Microsoft office excel (2007) was used in drawing all figures.

\section{RESULTS AND DISCUSSION}

The governorate of Fayoum was selected as a study area for many reasons: 1) presence of various breeds of poultry including the well known Fayoum breed, 2) acquaintance with the poultry sector through the strong presence of the Animal Production Research Institute (ARRI) projects, especially El-Azab Integration Poultry Production Project which was established in 1970,and 3) high poultry production since Fayoum ranks as the sixth among all governorates of Egypt in producing eggs(7.31 millions) and chickens (6.73 millions) and it also contains a large number of holdings (196.4 thousand) in which 11.12 million birds are raised (MALR,2005) .

Two different poultry production systems were identified in the study area 1) The traditional mixed crop/ livestock system where poultry and, animals are kept on a small land area owned by the farmer who also practices crop production, and 2) landless poultry production where the poultry farmer owns no land. The results of the field survey (Fayoum, 2007) showed that $40 \%$ of the sampled farmers followed system (1), and $33 \%$ followed system (2). Within each system, egg production and meat production were treated as separate activities.

A. Economic Features: Opportunity cost approach was adopted for economic analysis in this study rather than financial analysis of cost of inputs and revenues of outputs. Cash values of variable costs included price of purchased chickens, feed, labor, veterinary services and drugs, litter, and water and power. As most of the labor used in the rural sector is unpaid family labor, the cost of labor was estimated according to the current rates in the study area. Revenues of the layer production included price of eggs, culled birds after termination of the laying season, and manure. Revenues of meat production included price of the sold broilers and manure.

Measures of economic efficiency were estimated for the two poultry production systems in the study area besides comparing the cost of variable cost to the gross revenues of the farms. Also, the relative importance of the value of inputs and outputs were calculated. 
1. Egg Production: Table (2) shows the cash value of the variable costs and revenues in addition to measures of economic efficiency of laying farms in the two different systems at the study area.

The total variable costs for the bird per cycle are higher in the second system (landless) than in the first system (traditional) as it reached about LE 55.02and LE45.50 respectively. The increase in the variable cost in the second system may be due to the increase in cost of feeding for the bird per cycle under this system.

As shown in figure (1) the largest item of the variable costs in both systems was feeding since it represented $78.77 \%$ and $84.19 \%$ in the two systems, respectively. The cash value of feed in system (2) exceeded that in system (1) which seems logical as under system (1), the farmer produces, rather than purchases some ingredients like green fodder and grains. The differences in feeding, labor, and total variable costs are significant at the level shown in table (2).

The total revenues in the second system were higher than that of the first system (about LE. 81.14 and LE. 75.71 respectively per bird/cycle). The difference in the revenues of the sold breeders and manure at the end of the breeding cycle between the two studied systems, were significant at $\mathrm{p}<0.0001$ (table 2)

Table 2. Mean cash values and standard errors of variable cost and revenue items and economic efficiency of egg production in the study area as affected by system (LE/bird/cycle*)

\begin{tabular}{|c|c|c|c|}
\hline \multirow{3}{*}{ Variable } & \multicolumn{2}{|c|}{ Production System } & \multirow{3}{*}{$\begin{array}{c}\text { Significance } \\
\text { Level }\end{array}$} \\
\hline & Traditional & Landless & \\
\hline & Mean \pm S.E & Mean \pm S.E & \\
\hline \multicolumn{4}{|c|}{ Variable Cost } \\
\hline Price of purchased Chicks & $1.02 \pm 0.07$ & $1.10 \pm 0.05$ & ns \\
\hline Feeding & $35.84 \pm 1.63^{b}$ & $46.32 \pm 2.77^{\mathrm{a}}$ & $* *$ \\
\hline Labor & $4.27 \pm 0.31^{\mathrm{a}}$ & $3.27 \pm 0.24^{\mathrm{b}}$ & $*$ \\
\hline Litter & $0.24 \pm 0.07$ & $0.23 \pm 0.09$ & ns \\
\hline Water \& Power & $0.42 \pm 0.05$ & $0.38 \pm 0.04$ & ns \\
\hline Veterinary service \& drags & $3.74 \pm 0.89$ & $3.77 \pm 0.78$ & ns \\
\hline Total Variable Cost & $45.50 \pm 1.96^{\mathrm{b}}$ & $55.02 \pm 2.44^{\mathrm{a}}$ & $* *$ \\
\hline \multicolumn{4}{|c|}{ Revenues } \\
\hline Eggs & $60.80 \pm 2.75$ & $64.26 \pm 3.22$ & ns \\
\hline Breeders + manure & $14.91 \pm 0.30^{\mathrm{b}}$ & $16.88 \pm 0.36^{\mathrm{a}}$ & $* * *$ \\
\hline Total revenues & $75.71 \pm 2.82$ & $81.14 \pm 3.27$ & Ns \\
\hline \multicolumn{4}{|c|}{ Measure of economic efficiency } \\
\hline Gross Margin & $30.21 \pm 2.57$ & $26.12 \pm 3.24$ & ns \\
\hline Total revenues / total variable cost & $1.72 \pm 0.06$ & $1.54 \pm 0.09$ & ns \\
\hline
\end{tabular}

Means with different letters within each row and significantly different (Duncan 1955)

ns: not significant, $*=\mathrm{p}<0.05, * *=\mathrm{p}>0.01$, and $* * *=\mathrm{p}<0.001$

*note: cycle=year (12 months)

The measures of economic efficiency showed that the traditional system (1) was more efficient since the gross margin was equal to L.E. 30.21 as compared to L.E. 26.13 for system (2). Also the ratio of the total revenues / total variable costs was found to be L.E 1.72 in system (1) which was higher than system (2) of L.E. 1.54. Significant differences were found only between the mean of feeding cost, labor cost, and the total variable costs in the two studied systems. As far as revenues are 
concerned, differences between the mean values of the price of sold breeders and manure was also significant. The levels of significance for the differences are given in table (2).

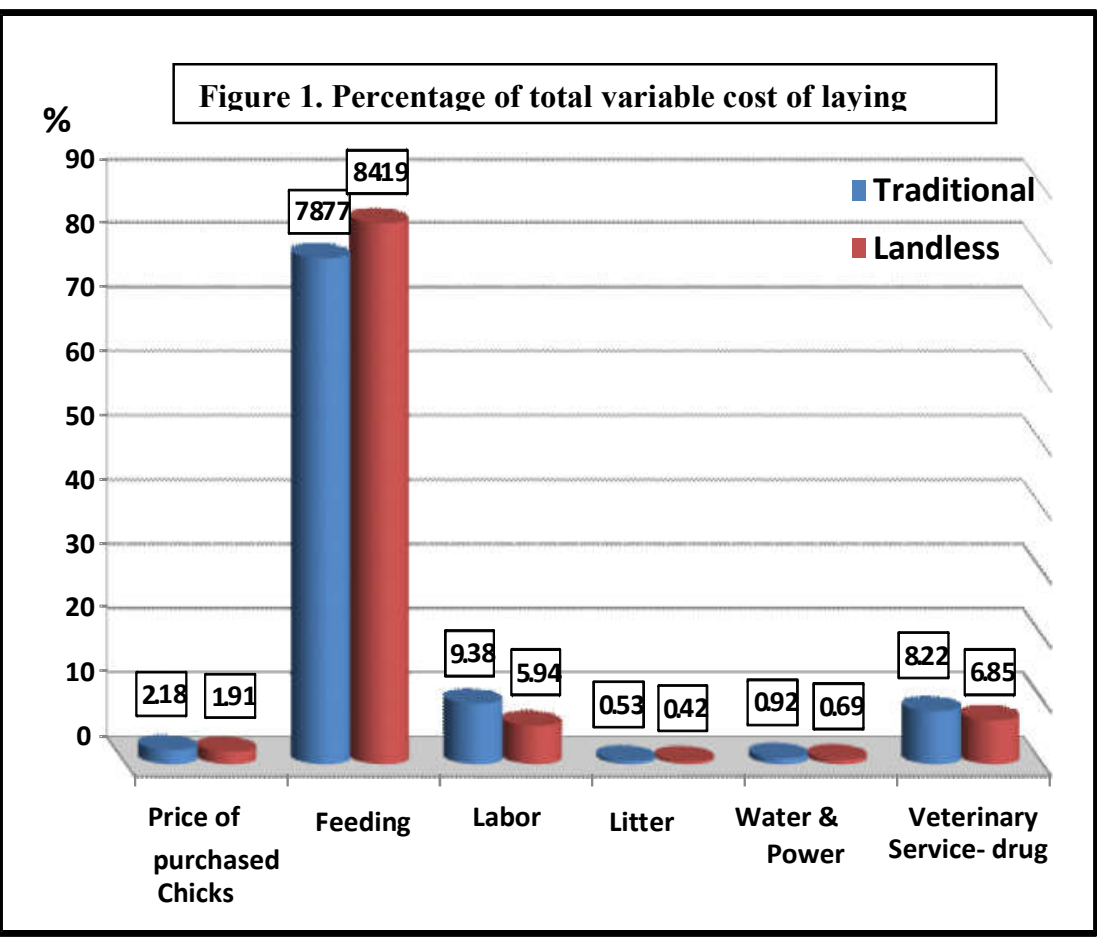

Duncan`s Multiple Range Test revealed no significant differences among the district means of all cost items, revenue items, and measures of economic efficiency (table 3). Similar results were found for the differences among village means (table 4).

However, rather obvious fluctuations were noticed in the cost of feeding, and the cost of veterinary service and drugs among districts and among villages. This might reflect the differences in the case given by the farmers to their flocks in the different districts and the different villages.

Analysis of variance (ANOVA) was performed to test the effect of the system, district, and village within district on the observations. Results of the ANOVA supported the results given in table (2) with respect to the effect of system on egg production. Among districts, significant effect was exerted only on cost of water and electricity which seems to depend on the source and availability. However, no significant differences were found among villages within districts for all variables (table 5).

2- Meat Production: As far as meat production from chickens is concerned, the results presented in table (6) show that farmers keep their birds for varying periods according to the system and breed. The common practice is to keep balady chicks for 5 months in both systems (1) and (2). 
Table 3. Mean cash values and standard errors of variable cost and revenue items and economic efficiency of egg production in the different districts of the study area (LE/bird/cycle*)

\begin{tabular}{|c|c|c|c|c|c|c|}
\hline \multirow{3}{*}{ Variable } & \multicolumn{6}{|c|}{ District } \\
\hline & 1 & 2 & 3 & 4 & 5 & 6 \\
\hline & Mean \pm S.E & Mean \pm S.E & Mean \pm S.E & Mean \pm S.E & Mean \pm S.E & Mean \pm S.E \\
\hline \multicolumn{7}{|c|}{$\begin{array}{l}\text { Variable Cost } \\
\end{array}$} \\
\hline Chicks price & $1.15 \pm 0.09$ & $1.19 \pm 0.13$ & $0.88 \pm 0.09$ & $1.07 \pm 0.11$ & $1.00 \pm 0.11$ & $1.05 \pm 0.12$ \\
\hline Feeding & $41.74 \pm 4.56$ & $36.50 \pm 3.74$ & $48.22 \pm 5.13$ & $35.94 \pm 3.05$ & $42.27 \pm 2.98$ & $40.13 \pm 4.74$ \\
\hline Labor & $3.75 \pm 0.33$ & $3.91 \pm 0.51$ & $3.13 \pm 0.32$ & $4.41 \pm 0.91$ & $3.70 \pm 0.33$ & $3.84 \pm 0.38$ \\
\hline Litter & $0.18 \pm 0.12$ & $0.39 \pm 0.23$ & $0.08 \pm 0.07$ & $0.21 \pm 0.12$ & $0.29 \pm 0.12$ & $0.26 \pm 0.13$ \\
\hline Water \& Power & $0.33 \pm 0.07$ & $0.24 \pm 0.03$ & $0.69 \pm 0.10$ & $0.44 \pm 0.08$ & $0.37 \pm 0.08$ & $0.35 \pm 0.08$ \\
\hline $\begin{array}{l}\text { Veterinary } \\
\text { service \& drug }\end{array}$ & $5.45 \pm 1.83$ & $3.72 \pm 1.32$ & $1.42 \pm 0.98$ & $3.40 \pm 1.35$ & $4.19 \pm 1.49$ & $4.22 \pm 1.63$ \\
\hline $\begin{array}{l}\text { Total Variable } \\
\text { Cost }\end{array}$ & $52.6 \pm 4.12$ & $45.79 \pm 4.36$ & $54.43 \pm 4.79$ & $45.42 \pm 3.56$ & $51.82 \pm 2.73$ & $49.85 \pm 4.62$ \\
\hline & \multicolumn{6}{|c|}{ Revenues } \\
\hline Eggs & $71.72 \pm 4.30$ & $62.91 \pm 3.99$ & $66.86 \pm 5.84$ & $53.75 \pm 4.37$ & $66.10 \pm 3.68$ & $55.27 \pm 6.17$ \\
\hline Breeders+manure & $16.82 \pm 0.48$ & $15.68 \pm 0.42$ & $15.77 \pm 0.61$ & $15.76 \pm 0.38$ & $15.15 \pm 0.75$ & $15.87 \pm 0.92$ \\
\hline Total Revenues & $88.54 \pm 4.54$ & $78.58 \pm 3.84$ & $82.63 \pm 5.89$ & $69.51 \pm 4.29$ & $81.24 \pm 3.62$ & $71.14 \pm 6.66$ \\
\hline \multicolumn{7}{|c|}{ Measure of economic efficiency } \\
\hline Gross Margin & $35.94 \pm 2.93$ & $32.79 \pm 3.45$ & $28.20 \pm 3.58$ & $24.09 \pm 4.70$ & $29.43 \pm 3.81$ & $21.30 \pm 7.77$ \\
\hline $\begin{array}{l}\text { Total } \\
\text { Total } \\
\text { cost }\end{array}$ & $1.73 \pm 0.09$ & $1.81 \pm 0.15$ & $1.55 \pm 0.10$ & $1.60 \pm 0.13$ & $1.60 \pm 0.09$ & $1.55 \pm 0.19$ \\
\hline
\end{tabular}

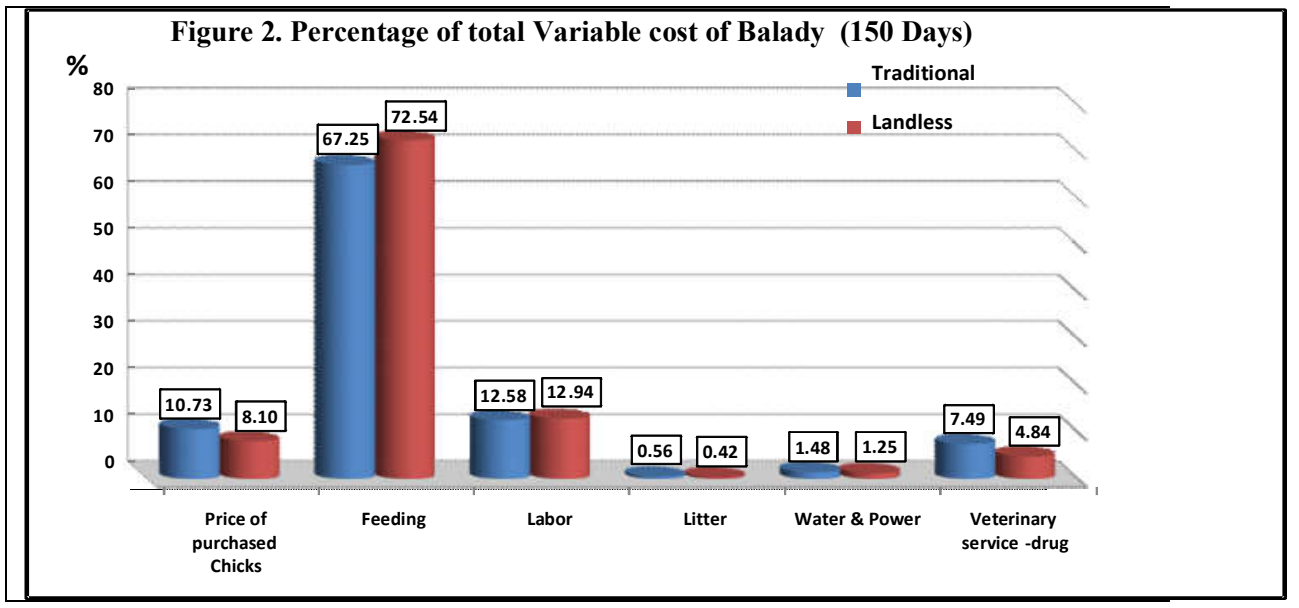

Cash values of both total variable costs and revenues are higher in system (2) than in system (1). As shown from table (6) the total variable costs and feeding cost are greater in the landless system than in the traditional system $(\mathrm{P}<0.05)$. This seems logical as in the landless system, farmers are more dependent on purchased feed. Feeding cost is the highest cash item of variable costs ranging from LE. 7.27 and LE. 8.69 in both systems. Cost items are represented as percentages of total variable costs in figure 2. 
Judged by the measures of economic efficiency (table 5) it can be concluded that the traditional system was found to be more economically efficient than the landless system. Significant differences $((\mathrm{P}<0.01))$ between means were found in most cases. No significant differences among district means and among village means were detected by Duncan's Multiple Range for all cost items, revenues, and measures of economic efficiency (Tables 7 and 8).

ANOVA of all cost items, revenues, and measures of economic efficiency were generally in agreement with the results presented in table 6 for the comparison between the traditional and the landless systems. On the other hand, no significant differences were found among districts and among villages within districts for all variables (Table 9).

\section{CONCLUSION}

The traditional system had the best results due to the low value inputs used in the production process. Egg production in the traditional system can be useful mainly for the purpose of home consumption and for generating job opportunities for family labor especially women and children.

It is worth noting that a third system was identified in the study namely the smallcommercial or the semi-commercial system. This system was not included in the study since its activities were not working in full operation because of temporary diseases situation during the course of data collection.

However, a separate study of this system will be carried out since preliminary results drawn from the current study showed that under this system, small commercial farms are relatively market- oriented, and farmers are aware of using advanced technology and can respond to efforts for improving their operations.

\section{ACKNOWLEDGEMENT}

The authors wish to express sincere gratitude to the National Academy of Science and Technology for financing this work. Also, acknowledge the assistance received from Dr. M. A. Ibrahiem, Dr. U. El-Said in the statistical analysis, and Prof. S. Galal for careful reading of the manuscript and valuable advice

\section{REFERENCES}

A.B.Sonaya and S.A.G. Sowan, 2004. Small-Scale. Poultry Production. (technical guide ) Food and Agriculture Organization of the United Nations .

Aichi.J.Kitalyi, 1995. Village Chicken Production Systems in Rural Africa Household Food Security and Gender Issues, FAO, Animal Production and Health .Vol: 142 pagination

Duncan, D. B., 1955. Multiple Rang and Multiple F tests. Biometrics, 11: 1 - 42.

Hassan M.S.S. et al., 2007. Local Breeds (raising, rearing, feeding and health care), Animal Production Research Institute, Ministry of Agriculture, Agriculture Research center, .Published by General Department of Agriculture Culture 
Ministry of Agriculture and Land Reclamation, Sector of Economic Affairs and Central Department of Agricultural Economics. Estimates of the National Agricultural Income(2004/2005)

Ministry of Agriculture and Land Reclamation. Central Department of Agricultural Economics. Sector of Economic Affairs. Important Statistical Features for the Animal, Poultry, Aqua and Bees Wealth, 2005.

Snedecor, C. W. and W. C. Cochran, 1981. Statistical methods. 7th ed. Iowa State coll. Press Ames I. A.

Statistical Package for Social Science (SPSS), 2006. SPSS Users Guide: Statistics, version 15 Edition. SPSS Institute, Inc., Cary, N. C. 
إقتصاديات إنتاج الدواجن في ظل نظم الإنتاج السائده منخفضة التكلفه بالقطاع الريفي ياسر أحمد عبدالعزيز'، حسن بيومي سمور'، أسامة محمود محمد زعتر'، محمد عبد العزيز

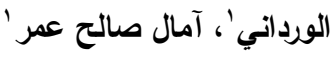

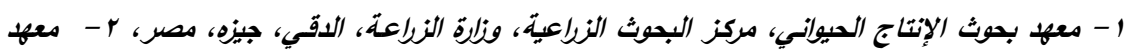

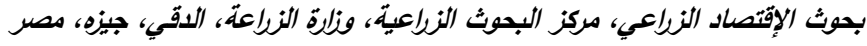

إستهفت هذه الدراسة نحليل الوضع الراهن للنظامين الأكثر شيوعا في القطاع الريفي في محافظة الفيوم

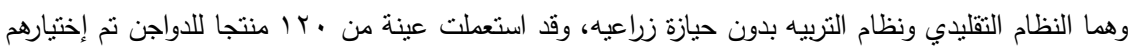

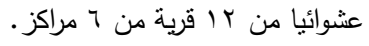
وقد جمعت البيانات أساسا من إستمارة إسنتيان ميدانيه كما رجعت الدراسة إلى المعلومات المنشوره في

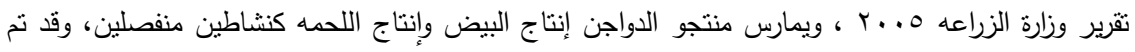

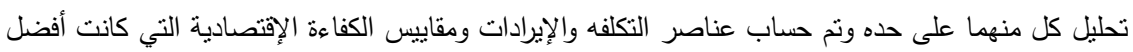

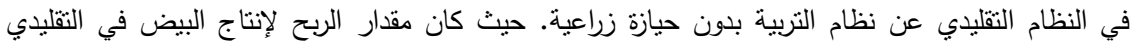

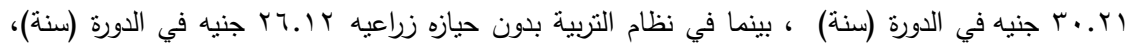

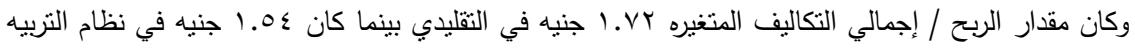

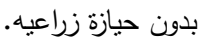

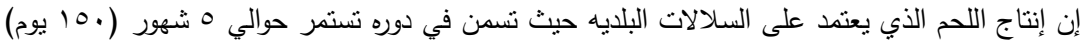

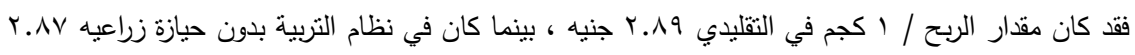

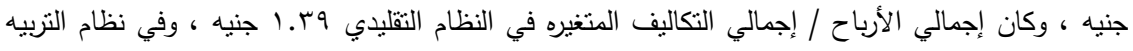

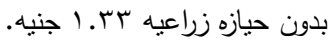



Egyptian J. Anim. Prod.,45 Suppl. Issue, Dec. (2008):99-109 